\title{
PENGARUH KOMITMEN ORGANISASI DAN BUDAYA ORGANISASI TERHADAP KINERJA KARYAWAN PT. CITRA MANDIRI CEMERLANG PRIMA
}

\author{
Muhammad Andre 1) \\ 1) Mahasiswa Program Studi Manajemen FE UNKRIS \\ Ahmad Hermanto ${ }^{2)}$ \\ 2) Dosen Program Studi Manajemen FE UNKRIS \\ Alamat: Kampus UNKRIS, Jatiwaringin Jakarta Timur \\ Email : hermanto.unkris@gmail.com
}

\begin{abstract}
To determine the Effect of Organizational Commitment and Organizational Culture on Employee Performance PT. Citra Mandiri Cemerlang Prima. This research is included in the category of causal associative research using a quantitative approach. The research was conducted by distributing questionnaires to respondents, all of whom were employees of PT. Citra Mandiri Cemerlang Prima, while the research method uses partially and simultaneous linear regression analysis. The hypothesis states that partially or simultaneous organizational commitment and organizational culture have a positive and significant effect on employee performance of PT. Citra Mandiri Cemerlang Prima.
\end{abstract}

Keywords: Organizational commitment, organizational culture and employee performance

\section{PENDAHULUAN}

Sumber daya manusia merupakan faktor penting dalam sebuah organisasi. Setiap organisasi juga akan selalu meningkatkan kualitas sumber dayanya agar kinerjanya memuaskan. Peningkatan kualitas tersebut juga merupakan salah satu upaya untuk menjadikan karyawan lebih termotivasi dan jelas arah tujuan yang ingin dicapai. Masalah tentang kinerja karyawan merupakan masalah yang perlu diperhatikan organisasi, karena kinerja karyawan akan mempengaruhi kualitas dan kuantitas organisasi dalam menghadapi persaingan seiring perkembangan zaman. Oleh karena itu memiliki sumber daya manusia yang berkualitas sangat dibutuhkan agar tujuan organisasi dapat tercapai dan dapat meningkatkan kinerja karyawan dalam suatu organisasi.

Apabila sumber daya manusianya memiliki motivasi tinggi, kreatif dan mampu mengembangkan inovasi, kinerjanya akan menjadi semakin baik. Kinerja yang baik tidak akan dihasilkan tanpa adanya faktor pendukung lainnya, banyak faktor yang dapat mempengaruhi kinerja karyawan. Sumber daya manusia "merupakan satu-satunya sumber daya yang memiliki perasaan, keinginan, keterampilan, pengetahuan, dorong daya, dan karya (rasio, rasa, dan karsa). Semua potensi sumber daya manusia tersebut berpangaruh terhadap upaya organisasi dalam mencapai tujuan". (Sutrisno 2016).

Oleh sebab itu sumber daya manusia memegang peranan yang sangat dominan dalam kegiatan organisasi. Berhasil atau tidaknya organisasi dalam mencapai tujuan sangat tergantung pada kemampuan sumber daya manusia atau karyawannya dalam menjalankan tugastugas yang diberikan sehingga pegawai dituntut untuk selalu mampu 
mengembangkan diri secara proaktif dalam suatu organisasi.

Sumber daya manusia yang diperlukan saat ini adalah sumber daya manusia yang memiliki kinerja maksimal (tinggi). Kinerja karyawan yang baik dapat dilihat dari berbagai sisi. Oleh karena itu, penilaian kinerja sangat perlu dilakukan oleh organisasi untuk mengetahui sejauh mana karyawan mampu berperan dalam perkembangan dan pertumbuhan organisasi.

Faktor yang mempengaruhi kinerja antara lain; ketersediaan peralatan dan barang, lingkungan kerja, job description dan tanggung jawab, visi, misi dan budaya organisasi, sistem komunikasi dan cara kerja pimpinan, adanya pelatihan dan pengembangan diri karyawan, serta adanya bunus dan insentif yang paling krusial dalam meningkatkan motivasi kerja karyawan.

Kualitas sumber daya manusia yang berpengaruh kuat terhadap kinerja karyawan adalah komitmen organisasi. Karyawan yang memiliki komitmen terhadap organisasi memiliki potensi untuk memperbaiki kinerja baik secara individual, kelompok maupun organisasi. Karyawan yang memiliki komitmen organisasi yang tinggi akan memberikan usaha yang maksimal secara sukarela untuk kemajuan organisasi. Mereka akan berusaha mencapai tujuan organisasi dan menjaga nilai-nilai organisasi. Selain itu, mereka akan berpartisipasi dan terlibat aktif untuk memajukan organisasi. Karyawan yang dimiliki komitmen yang tinggi akan bertanggung jawab dengan bersedia memberikan seluruh kemampuannya karena merasa memiliki organisasi. Rasa memiliki yang kuat akan membuat karyawan merasa berguna dan nyaman berada dalam organisasi.

Selain komitmen organisasi faktor lain yang dapat mempengaruhi kinerja karyawan salah satunya adalah budaya organisasi, kinerja yang baik tidak akan dihasilkan tanpa adanya budaya organisasi yang mendukung berjalannya organisasi itu sendiri. Budaya organisasi inilah yang kemudian mempengaruhi kinerja karyawan dalam mencapai tujuan organisasi. Robbins (2007) menjelaskan bahwa "budaya organisasi telah diketengahkan sebagai nilai-nilai, prinsipprinsip, tradisi dan cara-cara bekerja yang dianut bersama oleh para anggota organisasi dan mempengaruhi cara mereka bertindak". Pada hakikatnya semua organisasi memiliki budaya, namun tidak semua budaya organisasi sama kuatnya dalam mempengaruhi perilaku dan tindakan para karyawan. Semakin tinggi tingkat penerimaan para karyawan terhadap nilai-nilai pokok organisasi dan semakin besar komitmen mereka pada nilai-nilai tersebut, semakin kuat budaya organisasinya. Akan tetapi, budaya kuat juga memiliki kelemahan yaitu budaya organisasi yang kuat cenderung menghambat para karyawan untuk berani mencoba cara-cara baru, terutama dalam menghadapi situasi yang berubah cepat.

Dalam hal ini jelaslah bahwa budaya yang tertanam dalam organisasi memiliki kontribusi yang signifikan terhadap kinerja karyawan. Ketika karyawan memahami nilai-nilai yang ada dalam organisasinya, maka akan mempengaruhi bagaimana kinerjanya. Banyak faktor yang dapat mempengaruhi budaya organisasi, diantaranya komunikasi yang efektif mempunyai dampak yang positif terhadap budaya perusahaan, adanya upaya manajemen memotivasi karyawannya, karakteristik yang dimiliki organisasi, proses administrasi yang mudah dan gaya manajemen dalam menjalankan roda perusahaan.

PT. Citra Mandiri Cemerlang Prima adalah perusahaan bergerak dibidang jasa (penyediaan tenaga kerja). Yang berdiri pada tahun 1998 yang berfungsi menyelenggarakan jasa pelayanan kebersihan dan mencakup semua sektor seperti, pendidikan, keamanan, 
kebersihan dll. Sebuah perusahaan cleaning service yang memberikan pelayanan standar international di Jakarta selama lebih dari 20 tahun. Kami memeliki komitmen untuk selalu menjaga hubungan dengan klien kami lewat pelayanan terbaik serta memberikan dan menyediakan nilai-nilai yang dicari dan dibutuhkan oleh para klien kami.

Disini lah perusahaan harus mencari dan membuat sumber daya manusia yang sudah ahli dibidang-bidangnya, hal mencakup semua sektor kebersihan yang ada seperti kebersihan rumah tinggal, kebersihan kantor, kebersihan industry sebagainya. Kurangnya pemahaman terhadap komitmen dan budaya organisasi menjadikan karyawan yang kurang berkualitas. Banyaknya pelanggaran yang dilakukan karyawan seperti kerja belum optimal ditandai dengan banyaknya karyawan yang mondar-mandir dan acuh tak acuh dengan pekerjaannya.yang menyebabkan aduan klien kepada perusahaan untuk mengganti sumber daya manusia yang kurang baik dalam menjalankan tugas yang telah diberikan. Menurut perhitungan manajer, hampir $30 \%$ perusahaan menerima aduan atas kinerja karyawan dari klien. Itu berarti tingkat loyalitas karyawan di perusahaan masih rendah. Padahal komitmen dan budaya organisasi merupakan salah satu kunci yang turut menentukan berhasil tidaknya perusahan.

Tujuan penelitian ini adalah untuk mengetahui pengaruh komitmen organisasi dan budaya organisasi terhadap kinerja karyawan PT. Citra Mandiri Cemerlang Prima.

\section{LANDASAN TEORI}

\section{Komitmen Organisasi}

Komitmen adalah suatu janji yang diucapkan seseorang kepada dirinya sendiri dan orang lain, yang dicerminkan dari setiap tindakan atau pun perilaku yang dijalankannya. Komitmen sangat berkaitan erat dengan watak, sifat, dan karakter yang ada dalam diri seseorang.

Menurut Luthans (2009) yang menyatakan komitmen organisasi merupakan: 1). "Keinginan yang kuat untuk menjadi anggota dalam suatu kelompok. 2). Kemauan usaha yang tinggi untuk organisasi. 3). Suatu keyakinan tertentu dan penerimaan terhadap nilainilai dan tujuan-tujuan organisasi”. Menurut Greenberg and Baron (2005) mengatakan komitmen organisasi adalah "kesediaan seorang karyawan untuk memihak pada suatu organisasi tertentu dan tujuan-tujuannya serta berniat untuk memelihara keanggotaan dalam organisasi tersebut". Selanjutnya menurut. Griffin (2010) mengatakan "seorang individu yang memiliki komitmen yang tinggi kemungkinan akan melihat dirinya sebagai anggota sejati organisasi, dan untuk melihat dirinya sendiri menjadi anggota jangka panjang dari organisasi. Sebaliknya, seorang individu yang memiliki komitmen rendah lebih cenderung untuk melihat dirinya sebagai orang luar, dan mereka tidak ingin melihat dirinya sebagai anggota jangka panjang dari organisasi”.

Komitmen organisasi menurut Robbins (2007) merupakan "derajat sejauh mana seorang karyawan memihak pada suatu organisasi tertentu dan tujuan-tujuannya, serta berniat memelihara keanggotaan dalam organisasi itu".

Berdasarkan uraian tersebut, komitmen organisasi adalah hubungan antara karyawan dengan organisasi yang ditunjukkan dengan adanya keinginan untuk mempertahankan keanggotaan organisasi, menerima nilai dan tujuan organisasi serta bersedia untuk berusaha keras demi tercapainya tujuan dan kelangsungan organisasi.

Menurut Juniarari mengemukakan bahwa manfaat dari 
komitmen dalam organisasi yaitu diantaranya: 1). "Karyawaan yang serius dalam menunjukkan komitmen tinggi kepada organisasi memiliki kemungkinan yang jauh lebih tinggi untuk menunjukkan tingkat keikutsertaan yang tinggi dalam sebuah organisasi. 2 2). Memiliki kemauan yang kuat untuk tetap bekerja di organisasi yang sekarang dan selalu memberikan sumbangan untuk mencapai tujuan. 3).Dengan kesungguhan terlibat dengan pekerjaan, karena pekerjaan tersebut ialah mekanisme kunci \& saluran individu untuk memberikan sumbangan untuk tercapainya tujuan organisasi”.

Terdapat tiga faktor yang mempengaruhi komitmen organisasi "Meyer dan Allen, 2007" yaitu: 1). "Karakteristik Pribadi Individu;Karakteristik pribadi terbagi kedalam dua variabel yaitu variabel demografis dan variabel disposisional. Variabel demografis mencakup gender, usia, status pernikahan, tingkat pendidikan dan lamanya seseorang bekerja pada suatu organisasi. Sedangkan variabel disposisional mencakup, kepribadian dan nilai yang dimiliki anggota organisasi. Variabel disposisional ini memiliki hubungan yang lebih kuat dengan komitmen berorganisasi, karena adanya perbedaan pengalaman masing-masing anggota dalam organisasi tersebut. 2). Karakteristik Organisasi; Yang termasuk dalam karakteristik organisasi itu sendiri yaitu: struktur organisasi, desain kebijaksanaan dalam organisasi dan bagaimana kebijaksanaan organisasi tersebut disosialisasikan. 3). Pengalaman Organisasi; Sedangkan pengalaman berorganisasi tercakup ke dalam kepuasan dan motivasi anggota organisasi selama berada dalam organisasi, perannya dalam organisasi tersebut dan hubungan antara anggota organisasi dengan supervisor pimpinannya".

Indikator komitmen organisasi menurut Meyer dan Allen (2007) adalah: 1). "Komitmen afektif yaitu:
Emosional; Komitmen afektif menyatakan bahwa organisasi akan membuat karyawan memiliki keyakinan yang kuat untuk mengikuti segala nilainilai organisasi, dan berusaha untuk mewujudkan tujuan organisasi sebagai prioritas utama. b. Identifikasi; Komitmen afektif muncul karena kebutuhan, dan memandang bahwa komitmen terjadi karena adanya ketergantungan terhadap aktivitas-aktivitas yang telah dilakukan dalam organisasi pada masa lalu dan hal ini tidak dapat ditinggalkan karena akan merugikan. c. Keterlibatan karyawan dalam organisasional. 2). Komitmen berkelanjutan yaitu: a. Kerugian bila meninggalkan organisasi; Komitmen berkelanjutan merujuk pada kekuatan kecenderungan seseorang untuk tetap bekerja di suatu organisasi karena tidak ada alternatif lain. b. Karyawan membutuhkan organisasi; Karyawan yang tetap bekerja dalam organisasi karena karyawan mengakumulasikan manfaat yang lebih yang akan mencegah karyawan mencari pekerjaan lain. 3). Komitmen normatif yaitu: a. Social reward; Berupa dukungan rekan kerja dan supervisor serta suasana kondusif dalam hubungan internasional. b. Organizational reward; Berupa legitimasi jabatan, keamanan dan kenyamanan kerja, sistem gaji yang sesuai harapan".

\section{Budaya Organisasi}

Budaya organisasi adalah sistem kepercayaan dan sikap bersama yang berkembang dalam suatu organisasi dan membimbing perilaku para anggotanya. Selain itu, budaya organisasi juga dapat didefinisikan sebagai filosofi, ideologi, nilai-nilai, asumsi, kepercayaan, harapan, sikap dan norma-norma yang menyatukan suatu organisasi serta disebarluaskan oleh para karyawannya.

Menurut Hofstede dalam Wibowo (2013), menyatakan bahwa "budaya terdiri dari mental program bersama yang mensyaratkan respon individual pada 
lingkungannya". Definisi tersebut mengandung makna bahwa kita melihat budaya dalam perilaku sehari-hari, tetapi dikontrol oleh mental program yang ditanamkan sangat dalam. Sedangakan Wibowo (2013), adalah "sebuah persepsi umum yang dipegang oleh anggota organisasi, suatu sistem tentang keberartian bersama". Sedangkan menurut Menurut Rivai dan Mulyadi (2012) menyatakan bahwa budaya organisasi "adalah suatu kerangka kerja yang menjadi pedoman tingkah laku sehari-hari dan membuat keputusan untuk karyawan dan mengarahkan tindakan mereka untuk mencapai tujuan organisasi".

Budaya organisasi merupakan pola keyakinan dan nilai-nilai (Values) organisasi yang dipahami, dijiwai, dan dipraktikkan oleh organisasi, sehingga pola tersebut memberikan arti tersendiri dan menjadi dasar aturan berperilaku dalam organisasi. Oleh karena itu, budaya organisasi dijadikan sebagai pengendali dan arah dalam membentuk sikap dan perilaku manusia yang ada dalam organisasi. Budaya organisasi diharapkan akan memberikan pengaruh yang positif terhadap pribadia nggota organisasi maupun terhadap organisasi dalam hal mencapai visi dan misi serta tujuan organisasi.

Menurut Samdeep dan Lylesusman dalam Siswanto dan Sucipto (2008) mengklasifikasi sebelas ciri budaya perusahaan yang unggul. yaitu: 1). "Keyakinan yang tidak tergoyahkan bahwa manusia adalah sumber daya perusahaan yang paling penting. 2). Dukungan dari kewwirausahaan intern menghargai karyawan yang membantu perusaahaan yang tercapai misiya. 3). Pengendalian yang lebih didasarkan pada loyalitas dan komitmen ketimbang pada aturan dan kepatuhan.

4). Komitmen pada karyawan terhadap tujuan lebih tinggi ketibang komitmen mereka terhadap tujuan kelompok pribadi. 5).
Komitmen manajemen puncak untuk menyeaikan kebanggan di kalangan semua karyawan. 6). Komitmen manajemen puncak untuk mengahasilkan produk atau layanan yang unggul laiannya. 7). Keyakian akan kepentingan rirual, upacara dan pahlawan perusahaan. 8). Keyakinan akan pentingnya informasi kabar baik maupun kabar buruk. 9). Kesadaran bahwa komunikasi ke atas lebih penting daripada komunikasi ke bawah. 10). Dukungan manajemen puncak atas pelatihan dan pengembangan .komitmen untuk selalu lebih panadai dari pada pesaing. 11). Pandangan yang mengahargai kebearan mengambil resiko dan kreativitas".

Menurut Tosi, Rizzo, Carrol seperti yang dikutip oleh Munandar (2004), budaya organisasi dipengaruhi oleh beberapa faktor, yaitu: 1). "Pengaruh umum dari luar yang luas. Mencakup faktor-faktor yang tidak dapat dikendalikan atau hanya sedikit dapat dikendalikan oleh organisasi. 2 ). Pengaruh dari nilai-nilai yang ada di masyarakat. Keyakinan-keyakinan dn nilai-nilai yang dominan dari masyarakat luas misalnya kesopansantunan dan kebersihan. 3). Faktor-faktor yang spesifik dari organisasi. Organisasi selalu berinteraksi dengan lingkungannya. Dalam mengatasi baik masalah eksternal maupun internal organisasi akan mendapatkan penyelesaian-penyelesaian yang berhasil. Keberhasilan mengatasi berbagai masalah tersebut merupakan dasar bagi tumbuhnya budaya organisasi”.

$$
\text { Menurut Robbins dalam }
$$

Sudarmanto (2014) mengatakan, ada tujuh indikator utama yang secara keseluruhan menunjukkan hakikat budaya sebuah organisasi, yaitu: 1). "Inovasi dan keberanian mengambil resiko, yaitu sejauh mana karyawan didorong untuk bersikap inovatif dan berani mengambil resiko. 2). Perhatian pada hal-hal rinci, yaitu sejauh mana karyawan menjalankan presisi, analistis, dan perhatian pada hal- 
hal detail. 3). Orientasi hasil, yaitu sejauh mana manajemen berfokus lebih pada hasil ketimbang pada teknik dan proses yang digunakan untuk mencapai hasil tersebut. 4). Orientasi orang, yaitu sejauh mana keputusan manajemen dalam mempertimbangkan efek dari hasil karyawan dalam organisasi. 5). Orientasi tim, yaitu sejauh mana kegiatan-kegiatan karyawan dalam organisasi pada tim ketimbang pada individu-individu. 6). Keagresifan, yaitu sejauh mana orang bersikap inovatif, agresif dan kompetitif ketimbang santai. 7). Stabilitas, sejauh mana kegiatan-kegiatan organisasi dengan menekankan, dipertahankannya status quo perbandingan dengan pertumbuhan perusahaan".

\section{Kinerja Karyawan}

Kinerja karyawan adalah hal yang memiliki sifat individu, karena setiap karyawan memiliki tingkat kualifikasi yang berbeda dan kinerja yang berbeda dalam kaitannya dengan tugasnya. Manajemen dapat mengukur kinerja karyawan berdasarkan kinerja masingmasing karyawan tersebut.

Menurut Moeheriono (2014) menyampaikan pemahaman tentang kinerja karyawan atau definisi kinerja "sebagai hasil dari kinerja yang dapat dicapai seseorang atau sekelompok orang dalam suatu organisasi baik secara kualitatif maupun kuantitatif sesuai dengan wewenang, tugas, dan tanggung jawab mereka masing-masing. masingmasing dalam upaya untuk secara hukum mencapai tujuan organisasi yang bersangkutan tanpa melanggar hukum dan sesuai dengan moralitas atau etika". Sedangkan menurut Prawirosentono dalam Sutrisno (2016), kinerja adalah "pekerjaan seseorang, sekelompok orang dalam suatu organisasi yang sesuai dengan kekuasaan dan tanggung jawabnya masing-masing yang berusaha untuk mencapai tujuan organisasi yang dimaksud, tidak melanggar hukum, etis dan moral". Menurut Ccormick \& Tiffin dalam As'ad (2009), kinerja karyawan adalah "jumlah dan waktu yang diperlukan untuk melakukan kegiatan, waktu kerja adalah jumlah absen, keterlambatan dan durasi lamanya pekerjaan".

Alwi (2011) menyatakan menurut teorinya tujuan penilaian kinerja bisa dikategorikan sebagai sebuah sifat evaluasi dan pengembangan. 1). "Hasil penilaian dipakai sebagai dasar untuk memberikan kompensasi. 2). Hasil penilaian dipakai sebagai staffing decision. 3). Hasil penilaian dipakai sebagai dasar melakukan evaluasi sistem seleksi”.

Menurut Rivai (2014) manfaat penilaian kinerja pada dasarnya meliputi: 1). "Perbaikan prestasi, dalam bentuk kegiatan untuk meningkatkan prestasi karyawan. 2). Keputusan penempatan, membantu dalam promosi, perpindahan dan penurunan pangkat pada umumnya. 3). Sebagai perbaikan kinerja karyawan. 4). Sebagai latihan dan pengembangan karyawan. 5). Umpan balik sumber daya manusia. Prestasi yang baik atau buruk diseluruh perusahaan mengidentifikasikan seberapa baik Sumber Daya Manusianya berfungsi".

Menurut Robbins (2007) Untuk mengukur kinerja karyawan secara personal terdapat lima indikator yakni: 1). "Kualitas; Kualitas kerja dapat diukur dari persepsi karyawan terhadap kualitas pekerjaan yang dilakukan dan juga kesempurnaan tugas terhadap keterampilan dan kemampuan karyawan. 2). Kuantitas; Adalah jumlah yang diperoleh dinyatakan dalam istilah seperti jumlah unit, jumlah siklus kegiatan yang dirampungkan. 3). Ketepatan Waktu; Adalah tingkat aktivitas diselesaikan di permulaan waktu yang ditentukan. Dilihat dari sudut koordinasi dengan hasil keluar dan juga memaksimalkan waktu yang disediakan untuk kegiatan lain. 4). Efektivitas; Adalah tingkat pemakaian 
sumber daya organisasi tenaga, uang, teknologi, bahan baku secara maksimal dengan makdus menaikkan hasil di masing-masing unit dalam pemakaian sumber daya. 5). Kemandirian; Adalah tingkat seorang karyawan yang nantikan akan bisa melaksanakan fungsi kerjanya. Komitmet kerja adalah suatu tingkat yang mana karyawan memiliki komitmen kerja dengan instansi dan tanggung jawab karyawan terhadap kantor".

\section{METODE PENELITIAN}

Penelitian ini termasuk dalam kategori penelitian asosiatif kausal dengan menggunakan pendekatan kuantitatif. Penelitian dilakukan dengan menyebar kuesioner pada responden sebanyak 60 orang yang seluruhnya adalah karyawan PT. Citra Mandiri Cemerlang Prima, sedangkan metode penelitian dengan menggunakan analisis regresi linear sederhana dan berganda.

\section{HASIL PENELITIAN DAN PEMBAHASAN}

\section{Hasil Penelitian}

\section{Uji instrumen data}

Berdasarkan uraian tersebut di atas, maka untuk dapat menentukan apakah variabel komitmen organisasi dan budaya organisasi dapat dijadikan pengukur terhadap kinerja karyawan PT. Citra Mandiri Cemerlang Prima. Namun sebelumnya data diolah terlebih dahulu dan dilakukan pengujian terhadap varibel yang digunakan yaitu komitmen organisasi dan budaya organisasi dan kinerja karyawan untuk mengetahui apakah data tersebut akurat dan dapat dipercaya.

\section{Uji validitas}

Pengujian validitas ini dilakukan untuk menguji apakah tiap butir pernyataan telah mewakili indikator yang akan diteliti, persyaratan minimum untuk dapat dikatakan valid adalah $\mathrm{r}=0,30$. Jadi, apabila korelasi antara butir-butir item pernyataan dengan skor total kurang dari 0,30, maka butiran dalam instrumen tersebut dapat dikatakan tidak valid. Uji validitas dilakukan dengan melihat korelasi antara skor masing-masing item pernyataan dengan skor total. (Sugiyono, 2018).

Dari perhitungan koefisien korelasi skor tiap butir pernyataan instrument dari 60 responden tentang komitmen organisasi dengan jumlah 9 butir pernyataan; instrumen budaya organisasi 8 butir pernyataan dan instrumen kinerja karyawan 10 butir pernyataan dengan total skor setiap responden diperoleh hasil $r$ hitung lebih besar dari $\mathrm{r}$ kritis 0,30. maka seluruh item pernyataan didapatkan hasil yang valid.

\section{Uji reliabilitas}

Pengujian reliabilitas ini dilakukan untuk menguji seberapa jauh hasil pengukuran yang dapat diandalkan secarakonsisten. Pada tabel hasil pengujian reliabilitas berikut, diketahui bahwa semua variabel mempunyai alpha di atas 0,6 yang berarti bahwa semua variabel dalam penelitian ini dapat diandalkan.

Tabel 1: Hasil Uji Reliabilitas

\begin{tabular}{lccc}
\hline \multicolumn{1}{c}{ Variabel } & $\begin{array}{c}\text { Cronbach } \\
\text { Alpha }\end{array}$ & $\begin{array}{c}\text { Nilai kritis } \\
(\boldsymbol{\alpha})=\mathbf{5 \%}\end{array}$ & Keterangan \\
\hline Komitmen Organisasi & 0.758 & 0.800 & Reliabel \\
Budaya Organisasi & 0.680 & 0.800 & Reliabel \\
Kinerja Karyawan & 0.764 & 0.800 & Reliabel \\
\hline
\end{tabular}


Sumber: Data Primer, diolah tahun 2021

Berdasarkan reliabilitas cronbach alpha tersebut tampak bahwa seluruh pernyataan yang ada membentuk ukuran yang reliabel dari mulai komitmen organisasi, budaya organisasi, dan kinerja karyawan membentuk ukuran yang reliabel dari masing-masing variabel.

\section{Analisis regresi linear sederhana}

Tabel 2: Pengaruh Komitmen Organisasi Terhadap Kinerja Karyawan PT. Citra Mandiri Cemerlang Prima

\begin{tabular}{ccccccc}
\hline & \multicolumn{7}{c}{ Parameter } \\
\cline { 2 - 7 } Variabel & $\mathbf{R}$ & $\begin{array}{c}\mathbf{R} \\
\text { Square }\end{array}$ & Konstanta & $\begin{array}{c}\text { Koefisien } \\
\text { Regresi }\end{array}$ & Sig. & $\boldsymbol{\alpha}$ \\
\hline Komitmen_Org & 0.820 & 0.672 & 5.112 & 0.983 & 0.000 & 0.01 \\
\hline Pengujian Signifikansi & & & & & \\
\hline t hitung $>$ t tabel $=10.911>2.002$ & & & & \\
\hline
\end{tabular}

Keterangan : Variabel Kinerja Karyawan

Sumber: data diolah 2021

Berdasarkan Tabel 2, nilai koefisien determinasi $\left(\mathrm{R}^{2}\right)$ sebesar 0.672 , artinya komitmen organisasi memberikan kontribusi sebesar $67,2 \%$ terhadap kinerja karyawan PT. Citra Mandiri Cemerlang Prima, sedangkan sisanya sebesar $32,8 \%$ disumbangkan faktor lain.

Persamaan regresi $\mathrm{Y}=5,112+0,983 \mathrm{X}_{1}$
Komitmen organisasi berpengaruh positif dan signifikan pada tingkat nyata 99\% terhadap kinerja karyawan PT. Citra Mandiri Cemerlang Prima. Koefisien komitmen organisasi sebesar 0,983, artinya jika ada peningkatan komitmen organisasi, maka kinerja karyawan PT. Citra Mandiri Cemerlang Prima akan meningkat.

Tabel 3: Pengaruh Budaya Organisasi Terhadap Kinerja Karyawan PT. Citra Mandiri Cemerlang Prima

\begin{tabular}{lcccccc}
\hline \multirow{2}{*}{ Variabel } & $\mathbf{R}$ & $\begin{array}{c}\mathbf{R} \\
\text { Square }\end{array}$ & Konstanta & $\begin{array}{c}\text { Koefisien } \\
\text { Regresi }\end{array}$ & Sig & $\boldsymbol{\alpha}$ \\
\cline { 2 - 7 } & 0,668 & 4,325 & 1,118 & 0,00 & 0.01 \\
Budaya_Org & 0,817 & 0,668 & & 0 & \\
\hline & & & & & \\
\hline Pengujian Signifikan &
\end{tabular}

Keterangan: Variabel Kinerja

Sumber: data diolah 2021

Berdasarkan Tabel 3, nilai koefisien determinasi $\left(\mathrm{R}^{2}\right)$ sebesar 0.668 , artinya budaya organisasi memberikan kontribusi sebesar $66,8 \%$ terhadap kinerja karyawan PT. Citra Mandiri Cemerlang Prima, sedangkan sisanya sebesar $33,2 \%$ disumbangkan faktor lain.

Persamaan regresi

$\mathrm{Y}=4,325+1,118 \mathrm{X}_{2}$ 
Budaya organisasi berpengaruh positif dan signifikan pada tingkat nyata 99\% terhadap kinerja karyawan PT. Citra Mandiri Cemerlang Prima. Koefisien budaya organisasi sebesar 1,118 , artinya jika ada peningkatan budaya organisasi, maka kinerja karyawan PT. Citra Mandiri Cemerlang Prima akan meningkat.

\section{Analisis regresi linear berganda}

Tabel 4: Pengaruh Komitmen Organisasi dan Budaya Organisasi Terhadap Kinerja Karyawan PT. Citra Mandiri Cemerlang Prima

\begin{tabular}{lcccccc}
\hline \multirow{2}{*}{ Variabel } & Mult. R & $\begin{array}{c}\text { R } \\
\text { Square }\end{array}$ & Konstanta & $\begin{array}{c}\text { Koefisien } \\
\text { Regresi }\end{array}$ & Sig. & $\boldsymbol{\alpha}$ \\
\cline { 2 - 7 } & 0,868 & 0,754 & 0,111 & 0,560 & 0,000 & 0.01 \\
\hline $\begin{array}{l}\text { Komitmen_Org } \\
\text { Budaya_Org }\end{array}$ & 0,621 & 0,000 & 0.01 \\
\hline Pengujian Signifikan & \multicolumn{5}{c}{0} \\
\hline F hitung $>$ F tabel $=87,364>3,159$ & & & 0,000 & \\
\hline
\end{tabular}

\section{Keterangan: Variabel Kinerja}

Sumber: data diolah 2021

Berdasarkan Tabel 4, nilai $\mathrm{F}$ hitung sebesar 87,364 dibadingkan dengan $\mathrm{F}$ tabel sebesar 3,159, artinya secara bersama-sama komitmen organisasi dan budaya organisasi berpengaruh signifikan pada tingkat nyata $99 \%$ terhadap kinerja karyawan PT. Citra Mandiri Cemerlang Prima. Nilai Koefisien Determinasi $\left(\mathrm{R}^{2}\right)$ sebesar 0.754, artinya komitmen organisasi dan budaya organisasi memberikan kontribusi sebesar 75,4\% kepada kinerja karyawan PT. Citra Mandiri Cemerlang Prima, sedangkan sisanya sebesar $24,6 \%$ disumbangkan faktor lain yang tidak dibahas dalam penelitian ini.

Persamaan regresi

$Y=0,111+0,560 X_{1}+0,621 X_{2}$

Komitmen organisasi dan budaya organisasi berpengaruh signifikan terhadap kinerja karyawan PT. Citra Mandiri Cemerlang Prima, pada tingkat nyata $99 \%$. Koefisien komitmen organisasi sebesar 0,560 artinya jika ada peningkatan komitmen organisasi, maka kinerja karyawan PT. Citra Mandiri Cemerlang Prima akan meningkat dengan asumsi budaya organisasi tidak berubah. Koefisien budaya organisasi sebesar 0,621, artinya jika ada peningkatan budaya organisasi, maka kinerja karyawan PT. Citra Mandiri Cemerlang Prima akan meningkat dengan asumsi komitmen organisasi tidak berubah.

\section{Pembahasan}

\section{Pengaruh Komitmen Organisasi Terhadap Kinerja Karyawan PT. Citra Mandiri Cemerlang Prima}

Hasil penelitian menunjukan bahwa komitmen organisasi mendukung peningkatan kinerja karyawan PT. Citra Mandiri Cemerlang Prima. Hal ini menunjukkan bahwa karyawan senang menghabiskan sisa karir di perusahaan ini, masalah perusahaan merupakan bagian dari masalahnya, perusahaan memiliki banyak arti bagi karyawan, karyawan sulit meninggalkan perusahaan ini, berusaha bertahan karena kebutuhan dan keinginan, tidak ada pilihan dan bertahan di perusahaan ini, berpindah ke perusahaan lain sepertinya tidak etis, karyawan setia terhadap perusahaan dan karyawan sudah menjalani karir di perusahaan ini sudah 
sangat baik. Hasil penelitian ini sejalan dengan penelitian yang dilakukan oleh Girsang, (2019), dan Manery, et al, (2018) yang menyatakan bahwa komitmen organisasi berpengaruh positif dan signifikan terhadap kinerja karyawan, maka hipotesis pertama dapat diterima.

\section{Pengaruh Budaya Organisasi Terhadap Kinerja Karyawan PT. Citra Mandiri Cemerlang Prima}

Hasil penelitian menyatakan bahwa budaya organisasi dapat mendorong peningkatan kinerja karyawan PT. Citra Mandiri Cemerlang Prima. Hal ini dikarenakan bahwa karyawan sangat kuat mau melakukan inovasi dalam bekerja, upah sesuai dengan ketentuan yang berlaku, karyawan bekerja dengan teliti dan cermat, dituntut bekerja keras dan berkualitas, mempunyai hak yang sama dalam karir, sesama rekan kerja saling menghargai, bekerja denga cepat dan efisien, serta bekerja mengikuti prosedur yang telah ditetapkan. Hasil penelitian ini sejalan dengan hasil penelitian yang dilakukan Kuswati, (2020), Meutia dan Husada, (2019), yang menyatakan bahwa budaya organisasi berpengaruh positif dan signifikan terhadap kinerja karyawan, maka hipotesis kedua dapat diterima.

\section{Pengaruh Komitmen Organisasi dan Budaya Organisasi Terhadap Kinerja Karyawan PT. Citra Mandiri Cemerlang Prima}

Berdasarkan hasil analisis diketahui bahwa komitmen organisasi dan budaya organisasi dapat mendukung peningkatan kinerja karyawan PT. Citra Mandiri Cemerlang Prima. Hasil penelitian ini sama dengan hasil penelitian yang dilakukan Manery, et al, (2018), Meutia dan Husada, (2019), serta Burhan, et al, (2013) yang menyatakan bahwa komitmen organisasi dan budaya organisasi berpengaruh terhadap kinerja karyawan, maka hipoteis ketiga dapat diterima.

\section{KESIMPULAN DAN SARAN}

\section{Kesimpulan}

Setelah melakukan pembahasan, penulis akan mencoba menarik suatu kesimpulan yang dapat di sampaikan sebagai berikut: 1). Komitmen organisasi mendukung peningkatan kinerja karyawan PT. Citra Mandiri Cemerlang Prima. 2). Budaya organisasi mendukung peningkatan kinerja karyawan PT. Citra Mandiri Cemerlang Prima. 3). Komitmen organisasi dan budaya organisasi mendukung peningkatan kinerja karyawan PT. Citra Mandiri Cemerlang Prima.

\section{Saran}

Saran dan masukan yang dapat penulis berikan terhadap objek yang diteliti yaitu PT. Citra Mandiri Cemerlang Prima adalah sebagai berikut: 1). Komitmen organisasi yang terdapat pada perusahaan sudah bagus, hal ini dapat dirasakan oleh karyawan bahwa mereka merasa senang dapat menghabiskan sisa karirnya diperusahaan ini dan secara pribadi karyawan menyatakan bahwa perusahaan ini memiliki banyak arti, namun demikian ada juga yang perlu di ketahui oleh perusahaan bahwa karyawan tidak memiliki pilihan lain untuk bekerja di tempat yang lain sehingga mereka tetap bertahan. 2). Budaya organisasi yang ada pada perusahaan relatif cukup baik, ini terlihata dari karyawan yang sangat kuat dan keberanian untuk melakukan inovasi didalam menjalankan pekerjaannya, karyawan mau bekerja keras untuk menghasilkan kualitas kerja yang tinggi. Tetapi juga kiranya manajemen terus memperhatikan standar kerja karyawan apakah sudah sesuai dengan prosedur artinya stabilitas kerja karyawan perlu di awasi. 3). Bagi peneliti selanjutnya yang berkeinginan meneliti tentang pengaruh 
komitmen organisasi dan budaya organisasi terhadap kinerja, disarankan untuk menambah variabel-variabel lain yang lebih bervariasi dalam membahas yang berhubungan dengan kinerja karyawan di suatu bergerak dibidang jasa (penyediaan tenaga kerja).

\section{DAFTAR PUSTAKA}

Alwi, Syafarudin. 2011. Manajemen Sumber Daya Manusia. Edisi Kedua. Yogyakarta: BPFE Yogyakarta.

As'ad, Mohammad. 2009. Seri Ilmu Sumber Daya Manusia: Psikologi Industri. Edisi IV. Yogyakarta: Liberty

Burhan, Arif., Pradhanawati, Ari dan Dewi, Reni Shinta. 2013. "Pengaruh Budaya Organisasi dan Komitmen Organisasi Terhadap Kinerja Karyawan Dengan Mediasi Kepuasan Kerja Pada PT. BPR Setia Karib Abadi Semarang". Diponegoro Journal of Social and Politic Tahun 2013, hal. 1-13.

Girsang, 2019. "Pengaruh Budaya Organisasi dan Komitmen Terhadap Kinerja Karyawan RS Putri Hijau No. 17 Medan". Asian Journal of Innovation and Entrepreneurship. Vol. 04, Issue. 02, May 2019. Hal. 159-170. e-ISSN: 2477-0574; p-ISSN: 2477-3824.

Griffin, R. 2010. Komitmen Organisasi. Terjemahan. Jakarta: Erlangga

Greenberg. J dan Baron, Robert A. 2005. Budaya dan Komitmen Organisasi. Terjemahan. Jakarta: Erlangga

Hofstede, Geert. 2003. Culturas $e$ Organizacoes. Edicoes Silabo.

Juniarari. 2011. Komitmen Organisasi. Jakarta.

Kuswati. 2020. "The Influence of Organizational Culture on Employee Performance PDAM Majalengka”. Budapest International Research and Critics
Institute-Journal (BIRCI-Journal). Volume 3, No 1, February 2020, Page: 296-302 e-ISSN: 26153076(Online), p-ISSN: 26151715(Print).

Luthans, Fred. 2009. Perilaku Organisasi. Edisi Sepuluh. Yogyakarta: PT. Andi.

Manery, Benyamin Richard., Lengkong, Victor P.K dan Saerang, Regina T. 2018. "Pengaruh Komitmen Organisasi dan Budaya Organisasi Terhadap Kinerja Pegawai di BKDPSDA di Kabupaten Halmahera Utara". Jurnal EMBA, Vol. 6 No. 4. September 2018, Hal. 1968-1977. ISSN: 2303-1174.

Mangkunegara, Anwar Prabu. 2017. Manajemen Sumber Daya Manusia Perusahaan, Cetakan Kesepuluh, Bandung: PT. Remaja Rosdakarya.

Meutia, Kardinah Indrianna dan Husada, Cahyadi. 2019. "Pengaruh Budaya Organisasi dan Komitmen Organisasi Terhadap Kinerja Karyawan Koperasi Pegawai Perum Bulog". Jurnal Riset Manajemen dan Bisnis. Fakultas Ekonomi UNIAT. Vol. 4, No. 1 Februari 2019: 119-126. P-ISSN: 2527-7502, E-ISSN: 2581-2165.

Meyer, J.P. and Allen N.J. 2007. Commitment in the Worldplace Theory Reserch and Application, California: Sage Publications.

Moeheriono. 2014. Pengukuran Kinerja Berbasis Kompetensi. Edisi Revis. Jakarta: PT Raja Grafindo Persada

Munandar, AS. 2004. Peran Budaya Organisasi dalam Peningkatan Untuk Kerja Perusahaan. Jakarta: Bagian Psigokologi Industri dan Organisasi Fakultas Psikolog Universitas Indonesia.

Prawirosentono, Suryadi. 2008. Kinerja. Bandung: Alfabeta.

Rivai, Veithzal dan Mulyadi. 2009. Manajemen Sumber Daya Manusia. 
Cetakan Kesembilan. Depok: Penerbit PT. Raja Grafindo Persada. Rivai, Veithzal, 2014. Manajemen Sumber Daya Manusia untuk Perusahaan : dari Teori Ke Praktik, Edisi Pertama, Depok: Penerbit PT. Raja Grafindo Persada.

Robbins, Stephen P. 2007. Perilaku organisasi. Jakarta: PT Indeks.

Siswanto, Bejo dan Sucipto, Agus. 2008. Teori dan Perilaku Organisasi Sebuah Tinjauan
Interaktif. Malang: UIN Malang Press.

Sudarmanto. 2014. Kinerja dan Pengembangan Kompetensi SDM. Yogyakarta: Pustaka Pelajar. Sugiyono. 2017. Statikstika Untuk Penelitian. Bandung: Alfabeta.

Sutrisno, Edy 2016, Manajemen Sumber Daya Manusia, Cetakan Kedelapan, Jakarta: Prenamedia Group.

Wibowo. 2013. Perilaku Dalam Organisasi. Jakarta: Rajawali pers. 